\title{
Antitubercular Activity and Phytochemical Screening of Selected Medicinal Plants
}

\author{
RAJANDEEP KAUR ${ }^{1}$ and HARPREET KAUR ${ }^{2 *}$ \\ ${ }^{1} \mathrm{CT}$ Institute of Pharmaceutical Sciences Jalandhar, Punjab, India. \\ ${ }^{2}$ Lovely Professonal University Phagwara, Punjab, India. \\ http://dx.doi.org/10.13005/ojc/310176 \\ (Received: September 09, 2014; Accepted: October 15, 2014)

\begin{abstract}
Medicinal plants offer a hope for developing alternate medicines for the treatment of Tuberculosis.. The present study was done to evaluate in vitro anti-tubercular activity of five medicinal plants viz., Syzygium aromaticum, Piper nigrum, Glycyrrhiza glabra, Aegele marmelos and Lawsonia inermis. Solvent extracts of Syzygium aromaticum, Piper nigrum, Glycyrrhiza glabra, Aegele marmelos and Lawsonia inermis were tested in vitro for their activity against Mycobacterium tuberculosis H37Rv strain using Microplate Alamar Blue Assay. Activity in MABA was evaluated by lowest concentration of sample that prevents color change to pink. Extracts of all the five plants Syzygium aromaticum, Piper nigrum, Glycyrrhiza glabra, Aegele marmelos and Lawsonia inermis exhibited anti-tuberculosis activity, the proportion of inhibition of these plants extracts for M. tuberculosis H37Rv, inhibition was found to be $0.8 \mu \mathrm{g} / \mathrm{ml}, 50 \mu \mathrm{g} / \mathrm{ml}, 12.5 \mu \mathrm{g} / \mathrm{ml}$ and $50 \mu \mathrm{g} / \mathrm{ml}$ respectively. Our findings showed that all these plants exhibited activity against MDR isolates of H37Rv M. tuberculosis strain. Further studies aimed at isolation and identification of active substances from the extracts needs to be carried out
\end{abstract}

Key words: Mycobacterium tuberculosis, Mycobacterium Alamar blue assay, Antitubercular activity.

\section{INTRODUCTION}

Tuberculosis remains one of the major deadliest infectious diseases for humans. Approximately 9.2 million people develop the active disease each year, while 1.7 million cases of active disease result in death in the same period. The situation is worsening primarily because the association between tuberculosis and epidemic HIV/AIDS as well as the growing prevalence of multidrug-resistant (MDR) Mycobacterium tuberculosis strains ${ }^{1}$. These acute problems has led to search for structurally effective new drugs against this bacterium. It involves the search for structurally novel anti-tuberculosis natural products from higher plants ${ }^{2}$.

Medicinal plants offer a great hope to fulfill these needs and have been used for curing diseases for many centuries. These have been used 
extensively as pure compounds or as a crude material. Only a few plant species have been thoroughly investigated for their medicinal properties $^{3}$. Plants have been used worldwide in traditional medicines for the treatment of various diseases and it is estimated that even today approximately $65-75 \%$ of the World's population rely only on medicinal plants as their primary source of medicines ${ }^{4}$. India is one of the few countries in the World which has unique wealth of medicinal plants and vast traditional knowledge of use of herbal medicine for cure of various diseases ${ }^{5,6}$.

The phytochemical study of some of these plants has yielded a number of active natural products $^{7,8}$ thus the screening of natural products from higher plants constitutes one avenue in the search for new lead antitubercular agents. So far, few plants have been tested against mycobacteria and a few plants which showed anti-TB activity. The increasing incidence of MDR- and XDR-TB worldwide highlight the urgent need to search for newer anti-tuberculosis compounds/drugs ${ }^{9}$. Therefore, the present study was carried out to check the antimycobacterial activity of solvent extracts of five plants against $M$. tuberculosis H37Rv strain.

\section{MATERIALS AND METHODS}

\section{Collection of plants}

The buds of the plant Syzygium aromaticum ( Family Fabaceae), seeds of Piper nigrum (Piperaceae) \& rhizome of Glycyrrhiza glabra (Fabaceae) were purchased from the local market. The leaves of Aegele marmelos (Rutaceae) \& Lawsonia inermis were collected from their natural habitat. All the specimens were identified at D.A.V Ayurvedic College Jalandhar, Punjab.

\section{Extract Preparation}

The plant parts were shade dried and grind to fine powder. The crushed plant material was extracted with different solvents. For extraction, hexane, acetone and methanol were used as solvents. Extraction with Soxhlet apparatus was carried out. $700 \mathrm{~g}$ of plant material were extracted with hexane for 6-8 $\mathrm{h}$. The extract was concentrated under reduced pressure using rotavapour. The marc so obtained was subsequently extracted with acetone $(300 \mathrm{ml})$ for $6-8 \mathrm{~h}$. The extract so obtained was concentrated using rotavapour. The marc left behind was than extracted with methanol $(300 \mathrm{ml})$ for 6-8 $\mathrm{h}$. The extract was than concentrated. All the extracts were preserved at $5^{\circ} \mathrm{C}$ in airtight bottle for further use ${ }^{10}$.

\section{Phytochemical Screening}

All the extracts were dissolved in dimethyl sulphoxide (DMSO) and were used for the phytochemical analysis for the identification of various classes of chemical compounds alkaloids, carbohydrates, terpenoids, flavonoids, saponins using the standard protocol ${ }^{11-13}$.

\section{Antimycobacterial Activity}

The activity of all phytochemicals against the aforementioned $M$. tuberculosis strains was tested using the microplate Alamar Blue assay described previously ${ }^{14-15}$. Sterile distilled water (200 $\mathrm{ml}$ ) was poured into outer perimeter wells of the microplate. All other wells received $100 \mathrm{ml}$ of supplemented Middlebrook 7H9 broth, then working metabolites solutions $(100 \mathrm{ml})$ were poured into the first well of each row, from which two-fold dilution series were made through the microplate column. The test inoculum $(100 \mathrm{ml})$ was added to all testing wells, as well as to the drug-free control wells. The final concentration of DMSO in wells was $<1 \% \mathrm{v} / \mathrm{v}$. At the same time, 100:100,10:100 and 1:100 diluted controls were prepared from the bacterial suspension, representing the growth of 100,10 and $1 \%$ of the bacterial population tested. The final concentrations of metabolites tested ranged from 200 to $0.097 \mathrm{mg} / \mathrm{ml}$. Each concentration was assayed in duplicate. Each microplate was incubated for 5 days at $37^{\circ} \mathrm{C}$ in a $5 \% \mathrm{CO}_{2}$ atmosphere in a sealed plastic bag. After incubation time, one control growth was developed with a mixture of $20 \mathrm{~mL}$ of Alamar blue solution (Trek Diagnostics, Westlake $\mathrm{OH}$ ) and $12 \mathrm{~mL}$ of sterile $10 \%$ Tween 80 . The plates were re-incubated at $37^{\circ} \mathrm{C}$ for $24 \mathrm{~h}$. After incubation time, if the well turned pink, all the wells received the mixture of Alamar blue and Tween solutions in the same way and were incubated for an additional $24 \mathrm{~h}$. Wells with a welldefined pink color were scored as positive for growth. The Minimal Inhibitory Concentration (MIC) was defined as the lowest concentration of sample that prevents a color change to pink. Streptomycin, isoniazid, ethambutol and rifampicin were included 
as standard drugs. Each experiment was performed at least twice.

\section{RESULTS AND DISCUSSIONS}

Results obtained from the qualitative screening of phytochemical components from different plants performed on solvent extracts are presented in table 1. Almost all the plants taken for the study showed the presence of various classes of compounds including terpenoids, alkaloids, flavonoids, saponins and carbohydrates. The result of the anti mycobacterial activity by Alamar Blue Assay is presented in table 2 against H37RV a standard strain of Mycobacterium tuberculosis. Almost all the plant extracts showed antimycobacterial activity to different extents but methanolic and acetone extract of Syzygium aromaticum exhibited very good anti-TB activity having MIC of $0.8 \mu \mathrm{g} / \mathrm{ml}$ and $12.5 \mu \mathrm{g} / \mathrm{ml}$ respectively. The results of these extracts are compared diagramtically as depicted in Figure-1. Furthermore,

Table 1: Phytochemical screening

\begin{tabular}{|c|c|c|c|c|c|c|c|}
\hline \multirow{2}{*}{$\begin{array}{l}\text { S. } \\
\text { No }\end{array}$} & \multirow{2}{*}{$\begin{array}{l}\text { Class of } \\
\text { compound }\end{array}$} & \multirow{2}{*}{$\begin{array}{l}\text { Phytochemical } \\
\text { test }\end{array}$} & \multicolumn{5}{|c|}{ Plant species } \\
\hline & & & $\begin{array}{l}\text { Syzygium } \\
\text { aromaticum }\end{array}$ & $\begin{array}{c}\text { Glycyrrhiza } \\
\text { glabra }\end{array}$ & $\begin{array}{c}\text { Piper } \\
\text { nigrum }\end{array}$ & $\begin{array}{c}\text { Aegle } \\
\text { marmelos }\end{array}$ & $\begin{array}{c}\text { Lawsonia } \\
\text { inermis }\end{array}$ \\
\hline 1. & Terpenoids & Salkowski Test & + ve & + ve & -ve & + ve & + ve \\
\hline 2. & Alkaloids & Dragendorff's Test & + ve & + ve & + ve & + ve & + ve \\
\hline 3. & Flavonoids & Ferric chloride Test & + ve & + ve & -ve & + ve & + ve \\
\hline 4. & Saponins & Foam Test & + ve & +ve & -ve & -ve & + ve \\
\hline 5. & Carbohydrates & Benedicts Test & -ve & +ve & + ve & -ve & -ve \\
\hline
\end{tabular}

Table 2: Antimycobacterial activity

\begin{tabular}{lllccc}
\hline \multirow{2}{*}{ S. } & Plant species & Family & \multicolumn{2}{c}{ Mycobacterium tuberculosis H37Rv strain MIC $(\boldsymbol{\mu g} / \mathbf{m l})$} \\
\cline { 4 - 5 } No & & & Hexane & Acetone & Methanol \\
\cline { 4 - 5 } & & & - & 12.5 & 0.8 \\
1. & Syzygium aromaticum & Fabaceae & 50 & 12.5 & 50 \\
2. & Glycyrrhiza glabra & Fabaceae & 50 & 100 \\
3. & Aegele marmelos & Rutaceae & 50 & 50 & 100 \\
4. & Lawsonia inermis & Lythraceae & 50 & 50 & 50 \\
5. & Piper nigrum & Piperaceae & 50 & & \\
\hline
\end{tabular}

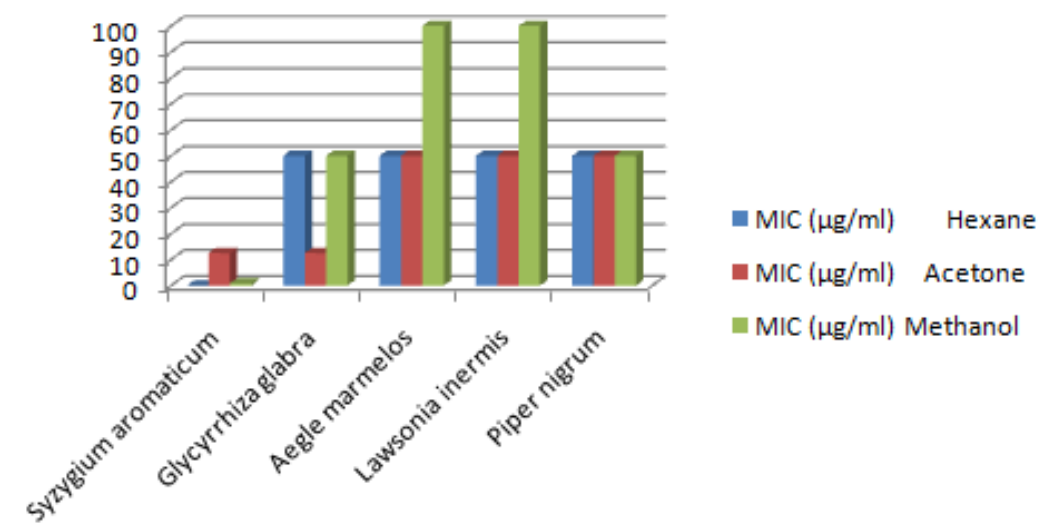

Fig. 1: Diagramatic representation of antimycobacterial activity of various extracts 
work is required to be undertaken for active principle or group of compounds responsible for such activity. The acetone extract of Glycyrrhiza glabra was shown to be very active as is quite evident from its MIC of $12.5 \mu \mathrm{g} / \mathrm{ml}$. The actual compound responsible for activity needs to be identified.

\section{ACKNOWLEDGEMENTS}

We are grateful to Dr. K.G Bhat \& his team at Maratha Mandal Dental College Belgaon, for carrying the antitubercular activity using Alamar blus assay and offering his valuable suggestions on the Alamar blue assay interpretation.

\section{REFERENCES}

1. World Health Organization, Global Tuberculosis control: surveillance, planning, finance. WHO report 2008, Geneva, 2008. (WHO/HTM/TB/2008.393).

2. Corona, M.R.; Hernandez, J.M., Journal of Mexican Chemical Society, 2009, 53 (2), 7175.

3. Heinrich, M.; Gibbon, S. Journal of Pharmaceutics \& Pharmacology, 2001, 53, 425-32.

4. Newton, S.M.; Lau, C.; Wright, C.W. Phytotherapy Research, 2000, 14, 303-322.

5. Gupta A.K. and Tandon,N., Review of Indian Medicinal Plants., Indian Council of Medical Research New Delhi, India; (2004).

6. Sharma S.K., Medicinal plants used in Ayurveda. National Academy of Ayurveda. Ministry of Health \& Family Welfare, Government of India, (1998).

7. Copp B.R. Natural Product Report, 2003, 20,
535-57.

8. Okunade A.L; Elvin Lewis, M.P.F.; Lewis, W.H. Phytochemistry, 2004, 65, 1017-1032.

9. Gupta, R.; Thakur, B. Indian Journal of Medicinal Research, 2010, 131, 809-13.

10. Mahesh B; Satish,S. World Journal of Agricultural Sciences, 2008, 4, 839-43.

11. Kumar, A.; Ilavarasan,R.; Aravindham, P.Pakistan Journal of Nutrition, 2009, 8(1), 83-85.

12. Khyade, M.S.; Vaikos, N.P. African Journal of Biotechnology, 2009, 8(22), 6434-36.

13. Gothandam, K.M.; Aishwarya, R.; Karthikeyan, S. Journal of Phytology, 2010, 2(4), 1-6.

14. Collins, L.; Franzblan, S.G. Antimicrobial Agents \& Chemotherapy, 1997, 41, 100410.

15. Jimenez-Arellanes, A.; Meckes, M.; Ramire, R; Torres, J. Phytotherapy Research, 2003, 17, 903-38. 